\title{
CULTURAL HERITAGE IN THE FOOD TRADITIONS OF THE SAKHA PEOPLE
}

\author{
I. Z. Borisova*, V. V. Illarionov, T. V. Illarionova \\ North-Eastern Federal University 58 Belinski str., Yakutsk, Republic of Sakha (Yakutia), \\ Russia, 677000
}

Published online: 08 August 2017

\begin{abstract}
The paper emphasizes the importance of studying the traditional Yakut/Sakha food as a historical, sociological, psychological and economic factor in the life of the ethnos.

The Sakha are one of the most ancient Turkic peoples. Throughout many centuries, the Sakha managed to preserve their food traditions. Life in severe conditions and sharp continental climate affected the specific features of the Sakha nutrition. The Turkic dishes of the nomadic peoples were adapted to the conditions of the North under the influence of the local inhabitants. This special feature is characterized by the use of northern fish and berries as part of nutrition, while the traditional northern meal mainly consisted of horse meat and dairy products. Like many other Turkic-Mongolian peoples, the Sakha subdivide all food into white/ҮрҮнас[urung as] (dairy food) and black/хара [khara] (meat food). In their cultural tradition, the Sakha would only begin eating the "black" food in winter after butchering cattle/uдэhэ [ideghe]. In summer, after the national holiday bIhblax [Ykhyakh] and during the haymaking season, the Sakha would eat "white" food and fish. Vegetables and flour were introduced to them later with the coming of the first Russians to the territory.
\end{abstract}

Key words: food traditions, cultural heritage, Turkic culture, white (dairy) food/urung as, black (meat) food/khara.

\section{INTRODUCTION}

The Republic of Sakha (Yakutia) occupies a fifth of the territory of the Russian Federation, 3.102 million square kilometers. This multinational Russian region has its own ethnic

Author Correspondence, e-mail: editor@academicpapers.org

doi: $\underline{\text { http://dx.doi.org/10.4314/jfas.v9i2s.850 }}$ 
specifics. Today, more than 100 nations live in the territory of Yakutia. In the middle of the first millennium, the ancestors of the Evens and Evenkis appeared on the territory of Yakutia. By the XIII century, the Tungus tribes settled along the Vilyui, Olekma and the middle reaches of the Lena. It is supposed that there were several waves of the Turkic tribes' migration to the territory of the modern Yakutia, the last of them occurring in the XIV-XV centuries. The Yakuts (self-designated as Sakha) as an ethnos,was formed in the Middlebasin of the Lena River by the amalgamation of the local paleo-Asiatic tribes and the migrating Turkic tribes, Mongolian Khoris and Tungus.

The spread of animal husbandrycaused significant changes in the life of the region. The ancestors of the Yakuts developed crafts — smith craft, gold work, pottery trade — and built permanent homes. By the beginning of the XVII century, the Yakut tribes spread to the basins of the Indigirka and Yana, advancing cattle breeding and horse herding to the Arctic regions of Yakutia.

Throughout their long history, the people of Sakha have developed their own original system of balanced nutrition with rational correlation of all its elements necessary for healthy metabolism. The nutrition style has come about as a result of close interaction with the neighboring peoples.

The importance of food in an ethnos' cultureand its social aspect were studied by the first explorers of the Yakut region including A. A. Savin, the first Yakut researcher who studied nutrition systematically. Many rituals, traditions and taboos are connected with food. The Yakuts prefer fatty and rich food, which is explained by the physiology of human body in conditions of the northern nature. Simple, low-calorie food was considered a sign of poverty: Om-масаһылыктаax [Ot-mas ahylyktaakh] — lit. They eat grass and trees. Fat and butterwere the main elements of Yakut ritual food and were believed to be the best food for gods: Арыьлаахалаадыьннанкүндүлээтилэр, саамалкымыһынанайахтуттулар [Aryylaakh alaadynnan kunduleetiler, saamal kymyhynan aiakh tuttular] — They were treated to pancakes with butter and koumiss. Baianaiu, the hunt god, was treated to fatty dishes; Aiyyhyt, the fertility goddess, liked the fatty porridge саламаат [salamaat].

The representation of food (ac, ahылыьк [as, ahylyk]), the concept ofnutrition (ac- үэл [asuel]) are among the most important concepts in the worldview of the Sakha. They are represented by a colorful play of words and images. The proverbs reflect the attitude of the ancient people of Sakha towards this concept, underlying the whole existence of the people. The concept of food is often represented through its connection with home, pleasure, feasts, awards for good work, and labor[1]. Difficult living conditions of the Sakha left their traces in 
the language. The basis of all the different cultures is known to contain the systems of values which manifest themselves in proverbs; the linguistic analysis of these proverbs helps to objectively distinguish some of the values in the cultures under comparison[2: 13].

Үчүгэйасхаальақынаақай, $\quad$ lit. Instead of letting tasty food rot, it куһақанисхаалльн [Utchugei as is better for the bad stomach to suffer. khaalyaghynaaghar, kuhaghan is khaallyn].

АскааБыйах, УлэБэугусүчүгэй [Aska lit. The fewer eaters the better, the aghyiakh, uleghe ugus utchugei]. more workers the better.

Халлаантанастүһүөдиэнайаххынатымла lit. Do not wait for food to fall down [Khallaantan as tuhyio dien aiakhkhyn from the sky. atyma].

Үлэнихаһааныма, ahыхаһаан [Uleni lit. Do not store work, store food. khahaanyma, ahy khahaan].

Үлэлээ, оччобоөллөнҮөң [Ulelee, lit. Work, and you will have food.

otchchogho iollionuion].

Сылдыьббытсыааһыльктаах, lit. The one who works, eats meat; the yтуйбутууаһыльктаах [Syldiubyt sya one who sleeps is only left with water. ahylyktaakh, utuibut uu ahylyktaakh].

Илиихамнаатабына, айаххамныьыр [Ilii lit. If the hand moves, the mouth will khamanaataghyna, aiakh khamnyyr]. chew.

Хоһуункиихоргуйбат [Khohuun kihi lit. A person full of energy will never khorguibat]. starve.

Кимсүрэбэлдьиир, олиһэаччыктылыры lit. The lazy ones always hear their [Kim suregheldiir, ol ihe atchtchyktyyr]. stomach growl. (Appeared in the Soviet period.)

Ким Үлэлээбэт, ол ahаaбат lit. Those who do not work, do not eat [Kimuleleebet, olahaabat]. either. (Appeared in the Soviet period.)

Үлэ ahamap, сүрэђэ суох ылmamap lit. Work feeds you, while doing [Uleahatar, sureghesuokhytatar]. nothing makes you cry later. (Appeared in the Soviet period.)

Aлаадьь арыьылаақа Үчүгэй, үлэ lit. It is good when oladii are with көхтөөуө ордук butter and work is with people. 
[Alaadiyaryylaaghautchugei, ulekiokhtioghioorduk].

In 1886,A. I. Shimansky, who studied the traditions of everyday life of the peoples of Yakutia, emphasized that, along with other reasons, food played a significant role in the Yakuts' struggle against the severe nature of the Lensky region. The national cuisine is determined by the food that helps the Sakha in their hard work. The Yakut food is very nourishing and nutritious, absolutely healthy and tasty as well. For this reason, the people of the North still keep to their traditional nutrition, passing on the recipes to the next generations, enriching and improving the national food and drinks. For a long time, the Sakha people have been laying their tables with various meat, fish, dairy disheswith plants and herbs [3: 10].

R. K. Maak, the researcher of the traditional way of life of the Sakha living in the Vilyusky region, noted the great significance of the Yakut food, which has a positive effect on human health. The people's food, customs and the way of life affect their health condition to a greater extent than the physical properties of the environment. Among the factors listed above, food plays the most significant role [4: 61]. In his research, he also noted that sour milkmap [tar] plays the main role in the local people's nutrition.

In 1842-1845, A. F. Middendorf organized an academic expedition to Yakutia. Later, remembering and carefully listing all the Yakut dishes that he had tried, he called salamat "a divine dish, the best food to please one's tongue and stomach" [5: 109]. V. L. Seroshevsky was also very impressed by this dish made of butter and flour, describing it as a wedding meal, the food of powerful spirits, rich people, sick people, and women in labor [6: 714]. Throughout the centuries, salamat has always been a unique and favored dish, served during special occasion meals. In addition, Middendorf gave a detailed description of making the thick drink уөрэ[uiore]—-pine sap — and wrote that it tasted“exceptionally nice” [6: 109].

The research publications of the pre-revolutionary period give detailed descriptions of different ways of making and eating traditional Yakut dishes. Dozens of different dishes and drinks can be made from milk. For example, I. A. Khudyakov colorfully describes cooking methods for 33 different dishes[7].

Professor M. A. Tyrylgin notes that with the coming of the Sakha, the northern nutrition style underwent significant changes. Before the Yakuts came, this vast region was inhabited by 30 northern peoples, yettheir nutritiondid not include milk, cream, sour cream, butter, cottage cheese, or any other dairy products, koumiss, tar, beef, horse meat, or sap flour. Having improvedtheir fishing tools, the Sakha greatly expanded the variety of fish in their nutrition as well [8]. 
S. I. Nikolaev (Somogotto), an ethnographer, describes the Yakut cuisine as multilayered, which makes it unique. It consists of the cuisines of the Yakut-speaking, Turkic-speaking, Tungus-speaking peoples, with Samoyedic layers and, finally, elements borrowed from the Russian cuisine[8].

In fact, with the coming of the Russians to the Yakut land, the local nutrition has changed and expanded greatly; people started growing wheat and potatoes; moreover, Russian оладьи [oladii] made from wheat flour have become an inseparable part of the traditional Yakut cuisine. The daily food of the old times, which consisted of horse ribs, belly bacon [khas], guts [kharta], liver, milk and cream foam, whipped cream, koumiss, salted fish, stroganina (sliced frozen fish), is returning to the traditional Yakut cuisine and is now considered to be delicatessen. These meals, which are very popular, are served at all festive events (weddings, anniversaries and other important occasions). Moreover, treating guests to some national meals is an important part of hospitality.

Since 1957, the Yakut cuisine has been experiencing a true Renaissance in the foodservice industry. The initiative of the Suntar region'scooks to revive the traditional food was supported by their colleagues from Nyurba and Ytyk-Kyuel, and the menus of cafeterias included salamat, керчэх[kerchekh] (whipped cream), суорат[suorat] (sour milk), koumiss, хаан[khaan] (blood sausage), ойогос[oiogos] (dishes made of colt ribs), Yakut soup, etc.[8]. In 1975, a brochure entitled "Yakut national meals" was published. It was created by Kholbos, a Yakut Republican Consumers Union and the Ministry of Trade of the Yakut Autonomous Soviet Social Republic (ASSR)[8].

I. I. Tarabakhov, an honored worker of the Yakut ASSR and honored trade worker of the Russian Federation, made a huge contribution to the professional description and systemization of the Yakut recipes that had been long forgotten. He combined the recipes in his book entitled Эностуолуцсахальыьастара [En ostuolun sakhalyy astara] — Yakut food on your table [9]. In the post-Soviet period at the end of the $1980 \mathrm{~s}$ - the beginning of the 1990s, the work on reviving, developing and promoting the traditional culture moved to a new level. The popularization of cultural heritage gained a new quality and goal; high-qualified young experts were actively engaged into the process of bringing the best traditions of the Sakha into life. During this period, nutrition as cultural heritage of the Sakha became a research topic. In 1989, a research seminar was held devoted to the problems of preserving, developing and popularizing the folklore of the Sakha. K. D. Utkin, E. N. Bokova, B. F. Neustroyev, V. D. Pinigina, M. N. Gabysheva, and I. I. Tarbakhov - distinguished representatives of science and culture - took part in this seminar. In 1992, the Yakut 
television began broadcasting a series of shows called Тарбаховталбаастарынтаабырыннара[Tarbakhov talba astaryn taabyrynnara] (lit. The secrets of Tarabakhov's magic kitchen). Since gaining sovereignty, Yakutia has undergone a stage of true rebirth of its national self-identity. The Yakut language has been recognized as a government language together with Russian. Schools have started teaching Yakut national culture, national book printing has gained popularity, etc. As one of the signs of the national culture revival serves the decision of the first president of the republic, M. E. Nikolaev, to open the first national cuisine restaurant Tygyn Darkhan. In 2005, the Vice-President of the republic A. K. Akimov and the Chair of the State Trading, Material and Technical Resources Committee R. I. Fedorov organized a very important event in the attempt to generalize the experience in restoring and popularizing healthy nutrition. This was a conference devoted to social nutrition in the Sakha Republic (Yakutia), its status, trends of development, and problems; it marked the 10th anniversary of the Tygyn Darkhan restaurant. Many distinguished citizens and scholars of Yakutia took part in this event [10: pp. 41-43].

The biggest achievement of this Conference was the publication of fundamental works by the outstanding Yakut ethnographers, such as A. A. Savvin, S. N. Nikolaev-Somogotto, I. I. Tarabakhov.

\section{URUNG AS - WHITE (DAIRY) FOOD}

Urung as, or white (dairy) foodplays a significant role in the Yakut nutrition. Travelers and researchers that visited Yakutia left good descriptions their dairy food. They, first of all, named the special features of the main Yakut drink of the warriors - koumiss. This drink was first mentioned in the memoires of Isbrand Ides and Adam Brand, who describedkoumiss as a kind of vodka made from milk, which the Yakuts usually drink during blhblax [ysyakh] (local festivals)[11]. V. L. Seroshevsky, who gave a thorough description of the Yakut way of life, called koumiss a drink which stirred appetite and filled people up with vital energy. According to him, young koumissgot into your nose because of a high concentration of carbon dioxide, and it made you slightly drunk, but not for long. It wore out quickly, gotcompletely digested; it enhanced the blood circulation and strengthened all the other natural processes in the human body.Along with horse meat, it remained a delicatessen for the rich people and it was praised in songs as the food of the heroes. Not very long ago, koumissused to be a very significant part of the Yakut nutrition. In 1896, Seroshevsky also noted that the local population preferredtheir traditional food to the Russian food. $\mathrm{He}$ emphasized that the elderly people of the time, like their ancestors, did not like the Russian food - tea, bread and sugar. They preferred the natural Yakut food - mare's milk and 
koumiss. They said that a person that drank them became strong and energetic[6].

Many researchers point out that the Yakuts can feed solely on koumiss all summer, because it is very high-calorie. Koumiss has a special place among the ritual dishes as a beverage that symbolizes divine grace. Only pure men used to be allowed to drink it during festivals. For a long time, people who had participated in funerals could not touch koumiss vessels for a while, as koumiss was considered to be the food for the most senior gods Aiyy. For a slightest violation of the sacred rituals and taboos, gods could punish the whole family.

Koumiss is called differently in different languages. In Turkic languages, it is represented by a word of the same origin; cf. the Yakut Kblмblc[kymys],the Tuvinian, Kirghiz, Kazakh and Bashkir $x b l M b l c\left[\right.$ khymys],the Kara-Kalpakian $x_{M b l 3}[\mathrm{khmyz}]$.The drink has a different name in the Buryat and Mongol languages - сэргээ[serge].

The descriptions and data provided by A. A. Savvin and M. A. Poryadin show that in the past, the Yakuts made three different types of koumiss:

(1)КөйҮҮкылмыс, көөнньүүкылмыскөйүргэн[kioiuu kymys] or [kionnyu kymys koiurghen]ripe strong koumiss with a larger concentration of alcohol and carbon dioxide. When consumed in large amounts, it might cause light drunkenness.

(2)Саамалкылмыс[saamal kymys] — fresh, short-brewed koumiss.

(3)Саамал кымысс[khara kymys] - koumiss made without adding butter, cream or cow milk during fermentation. Back in the old days, people used to add cream or boiled butter to koumiss before serving it. This way of serving was called aapax[arakh].Sometimes koumissis also made of cow milk, but the Yakuts do not call it koumiss, there is a different word for it - бbınnax or бblbinnax[byppakh] or [byyppakh][12].

The ritual porridge salamaat was used to gain favor of all the gods of the Yakut pantheon. It is made of flower sautéed in butter, which is later diluted with cream. Various kinds of salamaat are known, one of the most widespread is Aüblblhыmсаламаата[Аiуyhyt salamaata] - the salamaat of Aiyykhyt, the goddess of fertility. It was the food for the goddess, and also was given to women right after giving birth. Уруусаламаата [uruu salamaata] — wedding salamaat — was served during weddings, and special attention was paid to the process of cooking it. It was believed that if the wedding salamaat came out good at the first attempt, the marriage was going to be long and happy.

Cyopam [suorat]is a special Yakut type of sour dairy products. It resembles the Kazakh ayran, Russian varenets (clotted cream), or Ukranian ryazhenka (fermented baked milk), but it is quite different from all those drinks. Other dairy products are added into suorat and this gave it an additional name of $у м а$ [tuma], which stands for condiment. Thus, when speaking of 
suorat with tyma, one would need to add the name of the condiment. For instance, suorat with tuma made of barley porridge or suorat with sour cream tuma and so on. When edible plants and berries were added to suorat, the name of it was completely changed in some regions of Yakutia. Such suorat was calledақараан [agharaan]. The Turkmenshave the same name for sour milk without any plant condiments. Some Turkic peoples call it ayran. The following plants were added as condiment into suorat.

(1)Кииһилэ[kihile] — sorrel (Ruтехасеtosa). (2)Хааллаайылото or истии[khallaayyoto] or [istii]— angelica (Anqelicasilvestris).(3) Кириэн[kirien]—a Yakut variation of wild horseradish (Armoracia sisymbroides); it was added into suorat in small amounts, and only its young leaves were used. (4)Aaxma[aakhta] - pieplant (Rheum), only the young sprouts of this plant were used. (5)Сардаана[sardaana] — candlestick lily (Liliumdahuricum), only its bulb was used. Suorat with candlestick lily was considered to be one of the semi-delicatessen. (6)Моңуо[monguo] - a variety of lily (Lilium martagon); only the bulb of this plant was used in suorat. The lily bulbs were gathered in early spring or autumn. (7)Унньуула, күөлаһа, or ана5аһьын[unnuula], [kuol aha], or[anaghahyn] — different names for the same plant called susak or susatok by the Russians of Siberia (Butomusumbellatus). It was first crushed in a mortar to make flour, and then added to suorat. (8) Kубаahылызга[kuba ahylyga] - cattail (Typhalatifolia); itsflour and young rootswere mixed into suorat. (9) БІмызйax[ymyiakh] burnet (Sangnisorbaofficinalis); its roots cut into small crumbs were added into suorat.

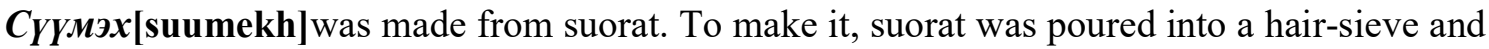
after a few hours, when all the whey was sieved out, what was left was suumekh - a dense cheesy substance.

Tap [tar]is a variety of sour milk stored for the future. Tar was always stored in a cold cellar in birch-bark vessels or wooden tubs. There are several versions of the Yakut tar: (1)pure tar without any additives; (2) tar with berries, sugarless jam made of red and black currant, huckleberry, blueberry, or brier berries used as a mixture to this tar; (3)tar with roots and herbs.

Бөлөнөх[byolyonyokh]is Yakut curdled milk. It was not cooked intentionally being an accidental result of non-boiledmilk getting sour.

Куөрчэx[kuertchekh] is a typical northern dish made of overchilled cream that is in a nearly frozen state. If the temperature is slightly higher, regardless of the skills and efforts, kuorchekh cannot be made. Kuorchekh is called differently in different parts of Yakutia, here are some of the names: дагда [dagda], көппөку [keoppeoku], көппөөку [keoppeoeoku],моруос[moruos]. The last name seems to belong to the Russian old-timers 
who spoke Yakut, possibly they were the Russians of the Russian Ustie (a village in the valley of the Indigirka River of Yakutia). V. L. Seroshevsky wrote about one of the types of kuorcekh (kyoppyoyoku), which resembled fresh whipped cream, "a very tasty drink" made of Arctic raspberry and wild strawberry boiled with cream and crushed into a creamy substance using a whisk. The berries turned the substance into a dense sweet-scented drink, which could truly be called "Yakut chocolate" [6].

Сардааналаахкөппөөкү[sardanalakh keoppeoku] is a dish which consists of fresh cream, whipped together with candlestick lily. Tarkoppoku koppoku is "a piece of the best tar whipped in milk and puffed up with a special whisk", - a description given by I. A. Khudyakov [7].

"Yakut women are skilled in making whipped cream (kuertchekh)", wrote R. K. Maak. In order to make whipped cream, there was a whole set of whisks of different shapes and forms in the household. The whipping was done very fast, and it was usually performed in a cellar, sitting on ice; moreover, in order to speed up the process, women added some ashes. Mixed with berries, whipped cream is called отонноохкерчях[otonnookh kuertchekh][4].

The description of dishes in the Dictionary of the Yakut Language by E. K. Pekarsky is very important for restoring ancient recipes. According to this dictionary, күөрчэх[kuertchekh](cf. Abak. Tat. korchik - a felt spindle for making sweet foam inboiled milk) is (1) a whisk for whipping cream ( and adding ashes; sweet whipped cream made with a whisk, (3) Yakut cream (dagda), to which sometimes crushed candlestick lily or berries were added (otonnokh kuertchekh). "Thisdish is considered to be a delicatessen, and it is served to very special guests" (13: 1320]. Dagda:(1) whipped cream made using a whisk, Yakut cream (kuertchekh); (2) dessert made of water (cream?) and milk, which is fermented with the help of a whisk [13: 662].

Moruos (cf. Rus. moroz = frost) is a dish which consists of a combination of frozen and crushed tar (milk that was fermented over the summer), with skimmed, or, preferably, not skimed milk; it is mixed using a whisk [13: 1594].

Үрүмэ[yurume]is a very difficult dish to make, it is also a delicatessen. In order to make it, Yakut pot makers designed special low and wide clay pots. Yurumeliterally means foam, that is, a thin layer of froth that is formed on the surface of milk heated for a long time.

There were other sour dairy products, such asиэдьэгэй[iyedzhegey] cottage cheese, хойуннарыллььбытүҮт[khoyunnaryllybyt yut]curdy milk, and milk with susak (flowering rush, Butomus umbellatus). 
Чохоон [tchokhon]is called differently in different regions of Yakutia. In Central Yakutia, it is called chokhon,in the Viluy region it is called көбүөр[kyebyuyer]and бөһҮүкэ[byehuke]. Chokhon is one of the oldest and most interesting Yakut dishes. Despite the popularity of this dish, in the 1950s it almost disappeared, and only recently the local expert chefshave started to cook it again.

ИтирдээхуYm [itirdeekh uut]is milk with beef abdominal fat. Pieces of the fat were put into boiling milk to make this dish.

Отонноохсуөгэй [otonnookh syuegey] - local berrieswith sour cream or cream; mashed blueberry or cowberry was mixed with sour cream or fresh cream and served.

Сугуннаах, отонноохуYm [sugunnakh] or [otonnokh yut]is cold milk mixed with blueberry and cowberry. Milk is boiled with roebuck berryand served cold.

Viluy agharaan is tar or suorat mixed with berries. In the past, berries that were put into tar were first boiled in water.Nowadays, this dish is prepared slightly differently, without boiling the berries first.

Өңүргэстээхуит [yengyurgectekh yut]is prepared by whipping boiled milk with a whisk. Then, the white and the yolk of a chicken egg are poured slowly into boiling milk. Theresultismilkwitheggflakes.

Food is a language of ethnic culture, and it has its own symbolism. It is demonstrated, for example, in oneiromancy - interpretation of dreams. Dreaming of milk products, "the white food" is a sign of wealth, gain and well-being, the more, the better. But if butter or chokhon don't beat well, and milk or cream turn sour quickly, they are clear signs of the intrusion of dark forces - абаahbl [abaahy].

Unlike many other cultures where it is habitual to talk during a meal, the Sakha culture praises silent meals. It is supposedly connected with a large amount of game and fish in meals and, therefore, the danger to choke. The ritual gathering for a meal, the order of dishes, the taboos on different food depending on sex and age are all specific ethnic features of the Sakha. The ritual meals have special significance at crucial moments of people's lives. They mostly consist of the "white food", but in most important occasions, cattle were butchered, which are the source of the "black food".

\section{KHARA - BLACK (MEAT) FOOD}

Khara, or black (meat) foodplays a significant role in the traditional meals of the nomadic people living in severe climatic conditions.

Koumiss, a white food dish, was the first important dish in sacred rituals. The second important food product was horse meat of the "black food".Horse meat was cooked at 
celebrations as well as funerals and commemorative rituals; a horse - хоолдьуга [khoolduga] — was slaughtered and buried together with the deceased. In the past, the Yakuts rarely ate meat; it was used as sacrifice food in the times of crisis, when the life-or-death issues were being solved.

Meat dishes have a special place in the Yakut cuisine and food traditions. Their popularity is self-evident: they are rich in vitamins, nutritious, and they have a remarkable ability to revive strength. For a long time, the Yakuts ate the meat of wild animals and fowl that inhabited their rich forested lands. Elk, deer and hare meat were considered to be special delicatessen.

Apart from ritual and sacramental, food had other common everyday meanings; some kinds of food were appropriate, others were forbidden, especially certain parts of game or fish. Among food rules, the dos and don'ts for pregnant women and children stand out. For example, it was forbidden for pregnant women to eat bear meat as it could lead to the child's having a bad temper. The kids who hadn't yet started to speak were forbidden to be given crucian tongue, which was otherwise considered a delicatessen, as the child could grow mute. Kids could not eat tongue tips, or they would become quarrelsome and cantankerous. Eating tail tips could result in profligacy. For many reasons, burbot, coot, gull, loon meat was tabooed for pregnant women. Yet, hunting and fishing, game and fish were very important in the Sakha's diet.

The years of drought, when hunters did not have much luck, were the hardest for the Yakuts. There were objective reasons as well as natural and climatic conditions that forced the human population to struggle for survival and to always keep cattle. Throughout the centuries, a unique breed of a Yakut cow and horse has been developed by adapting to the severe climate. The Yakut cuisine has its own equivalents of soups and second course dishes. The Yakuts have the following types of soup, which have their own names in the language: сулумахмин [sulumakh min],which is a broth, and сэлиэйдээхмин[selieideekh min].This kind of soup appeared later, when flour was introduced to the Yakut culture; the name of the soup reflects its Russian origin. Seliei is an adapted Russian word for "jelly" which originally comes from the French "gelée". Most Yakuts oups are cooked of meat products. For example, хааннаахмин[khannakh min]is made of wild reindeer or elkblood, which is added to broth. Исуөрэ[is yuyore]is made of cattle pluck. After a careful washing, heart, liver, guts, kidneys, tripe, and lungs of domestic animals were cut into small pieces, mixed and boiled, adding flour and onions. Чобочy[tchoghotchu]is made of pieces of horse or beef liver carefully wrapped into a layer of abdominal fat resembling a small pasty. The edges of the fat layer are kept together with a thin rod, and finally choghochu is boiled quickly in broth. 
The Yakuts are avid hunters, and use all kinds of meat in their dishes. The names of these dishes retain the names of the animals used in preparing them. For ехаmple, туллук[tulluk]is a dish made of snow bunting birds which are called tulluk in Yakut. Tosimplify the process of plucking feathers and dawn, the birds are frozen first and after that fried on a pan.

In the Yakut culture, there are many beliefs and taboos connected with eating bear meat. Meals with bear meat would turn into a full scale show. People would pretend that a raven was eating the bear meat, and they would imitatethe cry of a raven. Thebear's paw was stewed or fried as one piece and served on a large plate to the hunter himself or to a special guest. This dish is one of the most ancient hunting ritual dishes; to cut the paw is forbidden. In the past, this meal was served to young hunters as their first trophy.

Jyopnax[luorpakh] is a dish made of bear meat which is first stewed. Then, it is cut into small pieces, mixed with an equal amount of boiled bear's guts,poured with rendered abdominal fat of the bear and boiled; served hot together with the fat. Luorpakh is used during the ceremonial semi-ritual lunch after a lucky bear hunt. The same is done with elk meat and fat. Elk lips is a hunter's delicatessen, along with reindeer tongue. They are eaten both stewed and fried.

Duck meat is cooked in many different ways. Куссаламаam [kus salamaat] is duck pluck, stewed and cut into small pieces, poured over with warm duck fat, mixed and served. North Yakutian sausage is made of cleaned stomach or skin of large fish (taimen, burbot or others); it is further stuffed with stewed meat pieces of wild ducks and geese, covered with boiled fat and tied up.

The Yakuts make use of all body parts of homestead animals. For instance, a dish called мэйии[meyii]ismade of cattle brain fried with fat and onions, served only hot. Сэмсэ[semse] (Yakut: 'addition, supplement'[14: 367]) is a dish with small pieces of meat and onion rolled into a layer of abdominal fat; the edges of the layer are folded up several times and pierced with a rod. Симии[simii] is a type of sausage made of meat pieces mixed with wild onions and garlic together with abdominal fat,stuffed into a horse or beef gut and boiled. North Yakutian муоманай[muomanay]is made of stewed bowels covered with boiled fat. Этсаламаат [et salamaat] is made of stewed and dried meat cut into small pieces and fried in melted fat. This meal is common among the northern Yakuts. Central Yakutian $\boldsymbol{x a} \boldsymbol{x}$ [khaan] is a blood sausage which is made of fat guts of homestead animals. Different types of blood sausages are called differently: xapma[kharta](made of horse's large gut), бblblcac[byysas](made of cattle's large gut). When the guts are fat-free, some abdominal fat is cut into small pieces and added to the sausage together with the blood. Unlike khaan, north 
Yakutian субай [subay] is made not of fresh blood sausage but of blood that has been left overnight. Табахаана[taba khaana] is made of reindeer blood, poured intoa clean reindeer tripe. Хаанбутугас[khaan butugas] is a mixture of abdominal fat (cut into small pieces and dried)with blood; it is stewed in small amounts of water on a pan. Green onion, pepper and salt are used as condiments. Taar[taal] is made ofspleen, which is stuffed with a little abdominal fat previously cut into small pieces. Then, fresh blood is poured into it, seasoned with pepper and green onion. Next, it is tied up in the same way as other types of blood sausages. Taal is served only hot, right after it is prepared. In the past, the spleen sausage could only be eaten by the elderly people. It was a forbidden meal for all the young people. The taboo came from superstitious beliefs that if a young man or woman tries it, then in the most important moments of their lives (during hunting or in everyday life) they would be hit by a pain in the spleen.

In the Yakut cuisine, there are some analogs of hot and cold snacks, many of which are prepared using meat products. Чооцку[tchongku] is considered to be one the meat delicatessen of the north. It is bone marrow from the shin or the hip bone of elk, domestic and wild reindeer.

Horse meat for the Yakuts is a product of first priority. Силии[silii]is made of pipe bonemarrow of horses or cattle. Көмүруө[keumurue]is chunked heads of horse pipe bones; many people like to chew and suck out its limp, loose and spongeous part. Xaha[khaga] is horse visceral fat,caan[saal] is horse chine fat, both are served salted or frozen. Сынньbымm Yөс[synnjyy tues] is frozen chest gristle of a colt, which is chunked up into small pieces with a hatchet or any other sharp tool. This mince-like substance is mixed with small pieces of frozen khaga andcolt chest fat.Быар[byar] is colt liver which was usually served with salt,raw or frozen, as a cold snack. Horse stroganina was made of frozen horsemeat, which was cut into thin slices and served with onion, pepper and vinegar. Stroganina made of fat horse ribs had a special name — ойобос[oyoghos].Later, the Yakuts started to boil, smoke and force oyoghos. Yakutian horsemeat rollis made of the meat of the back and chest parts of horses and colts. Шашлык[shashlyk], үтүллүбүт[utullubut], саллыбытитир [sallybyt itir]are the dishes made of local sorts of meat fried on hot coals.

\section{$B A L Y K A S$ FISH FOOD}

Fishing for the Yakuts is a source of many rituals and taboos, which are still respected. Crucian fishing is a popular and widely spread type of fishing, very precious for the Sakha. In the past, for example, a person who had participated in a funeral ceremony was considered кирдээх [kirdeekh] - dirtyfor 40 days, and was not allowed to fish. Yakutia is the only place 
on earth that boasts a statue of crucian (coбo [sobo]).

Балькас [balyk as] — fish dishes — became a part of the nutrition culture with the migration to the north. The Yakuts of thecentral region ate fish only as a supplement to meat and dairy food, whereas the population of the northen and Viluy regions used fish as the main source of nutrition. River crucian, gudgeon, sterlet, omul, broad whitfish and dogfish were typical for the northern Yakut nutrition. The Yakuts, as well as other peoples, mastered different kinds of cooking fish — salt-drying, smoke-drying, drying on wooden sticks. Apart from this, the Viluy region Yakuts knew the technology of souring fish - сымa[syma], and they were called colnahbimmap[symahyttar] — syma eaters. This dish is similar to the Vietnamese smelly soured fish sauce. I. G. Vasiliev writes that a properly prepared syma is healthy, rich in vitamins and high-calorie [8].

Fish was used to make first and second course dishes. Балыкминэ[balyk mine], common fish soup, was made using perch, sterlet and taimen heads. There are many fish proverbs in Yakut: Эһиилгибилбаһынминсиэмдиэбиккэдыльь [Ehiilgi bil bahyn min siem diebikkedyly] - lit. As if there was an agreement that he would eat a fish soup from the head of taimen next year.

Sobo, or crucian, has a significant place in the worldview of the Yakuts. Having being the main source of protein for the poor farmers in the past, it is still popular today. The fishing ceremony has many traditions and taboos. Winter fishing for crucains turns into a real festival. The Kobiay region cruciansare especially popular. The Yakuts make хоһуламмытмин [khohulammyt min] - double fish soup with crucians. Large and fat crucians do not require long cooking time. If overcooked, they may fall apart. For this reason, crucian fish soup is usually quite light. First, a regular fish soup is cooked using small crucians or minnows, and once it is ready, large and fat crucians are added. Stuffed cruciansare made by stuffing them with crucian caviar and onions. Fried crucians are prepared without taking out the insides.

Истэхбуmyzaha [istekh butugaha]is made of caviar; the caviar is mashed in a plate with a spoon, salted, andboiled in a small amount of fishbroth whitened with milk. Балxaй[balkhai] is made of dog-fish heads, caviar and bowels in a small amount of water. Бүтэйбалык[butey balyk] is prepared using fresh fish fillet and caviar; first of all, mince is made by mashing the ingredients in a traditional arctic mortar. this mince,seasoned with salt, pepper and onion (or garlic),is stuffed into fish skin. Үтүмэx[utumekh] is prepared by kneading small fish into dough while it is still hot after frying on a grilling stick. Next, the dough is rolled into balls and fried on a pan — the utumekh is ready. Былаaбыm [bylaabyt] 
is made of boiled fish which is fried after removing the bones. Next, the crispy fish is mashed to a grain-like texture; hot fish fat is added, and served hot. Чэлээнэй [tcheleeney] is made of fish fillet; it is mashed together with a small amount of salt and green onion and rolled into balls. Талаха [talakha] is a gourmet kebab of small sterlets. The Yakuts also make kebab of river fish. Бааркы [barky] are fish toasts made of sun-dried Pacific salmon fried in boiling fish fat. БөтөБө[beuteugheu], куочука [kuotchuka] оrкуорумаан [kuorumaan],are prepared of well-washed, chopped insides of big fish, seasoned with green onion and pepper and boiled in a small amount of water. This meal is served as second course, hot,poredover with boiled fish fat.Fish in ashes is uneviscerated fish cooked by burying in hot ashes of a bonfire.

Cold fish snacks are very popular. First of all, it is stroganina, a cold fish snack made of thin slices of freshly frozen fish. The fish should be frozen immediately after it was caught; it is killed right after catching by hitting it hard on the head; then it is frozenon ice as fast as possible. Өрөцө [eureugheu] is made of the bellies of the fish used to make stroganina. Тоңистэх [tong istekh] — frozen caviar, frozen kebab, and frozen maksa (burbot liver) are served frozen.

\section{PLANT FOOD}

Plant food is not very popular in the Yakut culture, as evidenced by certain idioms and proverbs. Butthere are many plants that are used in Yakut dishes despite the popular saying: Сахаынахбуолбатах, отунанаһаабат [Sakha ynakh buolbatakh, otunan ahaabat] —A Yakut is not a cow, he does not eat grass.There are few edible plants in Yakutia, A. E. Kulakovsky mentions 19 types of them - wild onion, wild garlic, wood sorrel, wild horseradish, wormwood, candlestick lily, flowering rush, forest grass, etc. [15: 67]. Later, under the influence of the Russian cuisine, the local population started using other plants, adding them as condiments. The names of these plants in Yakut comprise a specific part of the vocabulary.

Кииһилэ[kiihile] — sorrel (Rumexacetosa) grows in damp valleys and pastures. The Yakuts used fresh cut sorrel leaves with milk and sweet suorat. Angelica (Angelica sylvestris) somewhat resembles cabbage, which is why it is sometimes called istii(a phonological adaptation of the Russianshchi-cabbage soup). The locals call it халлаaйbiomo[khallayy oto].It is used like common cabbage. Кэйигэсуга[keyighes uga]- silverweed cinquefoil (Potentillaanserina) was usually collected in autumn, when it finished blooming. Boiled silverweed cinquefoil powder was used as a condiment for milk and tar. The leaves of кириэн [kirien](cf. Rus.khren) — wild horseradish (Armoracia sisymbroides) — were used as 
condiment. When prepared for long-term storage, they were soured with tar. Wild onion and garlic are widely spread. They are stored and used in exactly the same way as the cultivated types of these plants. The bulbs of wild lilies_ candlestick lily (Liliumdahuricum), sardana, and pink lily (Lilium martagon), моңуо [monuo], are widely used. Flowering rush (Butomus umbellatus) is a water plant called уннуула [yunnula], күөлаһа [kuol agha], анақаһьн [anagakhyn] in Yakut. In autumn, the Yakuts went out into swampy lakes on boats and with special gaffs pulledout long black roots from the lake bottom. They also collected the roots from the bottom of lakes that went shallow. The valuable roots, collected with so much effort, were washed, dried and mashed by hand until the dark thin bark came off. Cleaned from the bark, the root was further ground into white flour similar to potato starch. Like flowering rush,кубааһылыга[kuba ahylyga], or бөөтүуртэбиэн[byetur tebien]— cattail (Typhalatifolia)grows in boggy-bottomed lakes. The Yakuts used its roots to make flour. The roots of burnet (Sanguisorba officinalis) are known as blмbiŭax[ymyyakh]in Yakut. They were eaten both raw and boiled (in porridge). Brier and wild strawberry were used to make a tea-like drink. Berries, such as cowberry (отон[oton]), bearberry (уулаахотон[ulakh oton]), wild strawberry (Әьэдьэн[djedjen]), blueberry (сугун[syugyun]), Arctic raspberry (ьтттиңилэээ[yt tingilege]), red currant (хапта5ас[khaptaghas]), black currant (моонньоБон[moniogon]), hawthorn berries (долохуна[dolokhuna]), bird berry (харас[kharas]), fen berry (моруоска[moruoska]), raspberry (биээмийэ[bieemiye]) were eaten fresh or frozen as well as an additive to dairy products. Unlike other northern peoples, the Yakuts did not eat berries with meat. Also, mushrooms were not used as food.

\section{CONCLUSIONS}

The Yakut cuisine can be rightly seen as their cultural heritage. It reflects the history of the ethnos, bears the mark of the climate, and reveals interethnic contacts. It embodies the worldview and beliefs of the people, has ritual and sacred meaning. Apart from simply being the means of sustaining physical life, it has important social functions, becomes a uniting factor in the life of the ethnos.

Yet, for a long time, food and nutrition traditions have not been recognized as part of the cultural heritage of the Yakut people. Now, as the situation has changed, the national recipes need to be revived and studied in two directions. On the one hand, they can broaden our knowledge of the Yakuts' physical, social and spiritual history. On the other hand, nowadays ethnic cuisine functions as an ethno-psychological, social and economic factor, emphasizing 
ethnic originality, promoting ethnic identity and developing ethnic tourism. The gourmet dishes of the Yakuts should take their place in gastronomy studies and in restaurant menus.

\section{REFERENCES}

1. Assotsiativnyi slovar yakutskogo yazyka [Associative dictionary of the Yakut language]. Cited 2016 Sept 16. Available from: httphttp://adictsakha.nsu.ru.

2. Borisova IZ. Kontsept 'lyubov' v poslovichnoi kartine mira vo frantsuzskom i yakutskom yazikakh. [The concept of 'love' in the world picture of the French and Yakut languages]. Vestnik Buryatskogo Gosudarstvennogo Universiteta [Journal of Buryat State University] 2013; 11:13-16.

3. Shimansky AI. Pishcha yakutov [Food of the Yakuts]. St. Petersburg: Izvestia VSOIRGO. 1885. - Vol. 16. - pp. 310-319.

4. Maak RK. Viluysky okrug Yakutskoi oblasti [Viluysky district of the Yakut region]. St. Petersburg: Tipografia I khromolitografia A. Tranchelia, 1886. p. 504 c.

5. Middendorf AF. Entsiklopedia Yakutii [Encyclopedia of Yakutia]. Vol. 1. Yakutsk: Izd. YNC SO RAN, 2007, pp. 109-1027.

6. Seroshevsky VL. Yakuty [The Yakuts]. St. Petersburg: izd. Znanie; 1896. vol. 1, pp., 1908-1909

7. Khudyakov IA. Kratkoye opisaniye Verkhoyanskogo okruga [A brief description of the Verkhoyansky district]. Leningrad: Nauka; 1969.

8. Istoriia Yakutska [Yakutsk history]. Cited 2016 Sept 20. Available from: http://www.yakutskhistory.net.

9. Tarabakhov I.I. (1993) En ostuolun sakhalyy astara[Yakut food on your table]. Yakutsk: Bitchik; 2005.

10. Illarionov V.V. Yakut national cuisine: tradition and modernity/ Sostoyaniye, napravleniye rasvitiya, problemy. Proceedings of the scientific conference on "Social nutrition in the Sakha Republic (Yakutia): condition, trends of development, problems"//Materialy naucho-prakticheskoy konferentsii "Obshestvennoye pitaniye v Respublike Sakha (Yakutia): devoted to the 10-year anniversary of the Tygyn Darkhan restaurant), Yakutsk: Bitchik;2005, pp. 41-43

11. Ides I, Brand A. Zapiski o russkom posolstve v Kitai (1692-1695) [Notes on Russian Embassy to China]. Moscow: Nauka; 1967.

12. Savvin AA. Yakutsky kyumys [Yakut koumiss]. In: Materials on Yakut ethnography, Yakutsk: Yakutskoe knijnoe izdatelstvo; 1948, pp. 117-138. 
13. Pekarsky EA. Slovar yakutskogo yazyka [A dictionary of the Yakut language]. Vol.1-3. Moscow: Izd.akademii nauk SSSR; 1958-1959.

14. Yakutsko-russkiy slovar [Yakut-Russian dictionary]. Moscow: Sovetskaya Entsiklopediya; 1972.

15. Kulakovsky AE. Nauchnye trudy [Research works]. Yakutsk: Yakutskoe Knizhnoe Izdatelstvo; 1979.

How to cite this article:

Borisova I Z, Illarionov V V, Illarionova T V. Cultural heritage in the food traditions of the sakha people. J. Fundam. Appl. Sci., 2017, 9(2S), 1388-1405. 